\title{
Deciphering the role of APP in synaptic function
}

\author{
Hui Zheng \\ From 2011 International Conference on Molecular Neurodegeneration \\ Shanghai, China. 22-24 September 2011
}

\section{Background}

Genetic and biochemical studies establish a central role of the amyloid precursor protein (APP) in Alzheimer's disease (AD): genetic mutations and gene amplification of $A P P$ are linked to a subset of early onset familial Alzheimer's disease (FAD), and APP processing generates $\beta$-amyloid (A $\beta$ ) peptides, which are the principal components of the amyloid plaque pathology. Although $\beta$-amyloid plaques are the hallmark of AD, synaptic dysfunction closely correlates with cognitive impairment and is recognized as a causal event leading to $A D$ pathogenesis. Since $A \beta$ is naturally generated along with other products through APP processing, investigating the role of APP and its cleavage products in synaptic function and dysfunction is critically important in understanding $\mathrm{AD}$ pathogenesis.

\section{Results}

We seek to understand the physiological functions of APP in neurons and synapses using in vivo mouse models and in vitro culture systems. Analysis of the APP knockout mice allows us to identify a functional role of APP in synaptic plasticity and learning and memory. Our investigation of mice deficient in APP and its homolog APLP2 establishes an essential role of APP family protein in mediating cholinergic synaptic structure and neurotransmission in both peripheral neuromuscular synapse and central cholinergic neurons. By creating an APP conditional allele, we demonstrate that APP is required in both pre- and postsynaptic terminals; and that pre- and postsynaptic APP interact to mediate synaptic structure and function. These in vivo findings are supported by in vitro mixed-culture studies, which reveal that APP potently induces synaptogenesis. Independent of the synaptic adhesion property that requires the full-length protein, we found that the soluble secreted APP ectodomain mediates transcription of genes related to aging and amyloid sequestration.

\footnotetext{
Huffington Center on Aging, Department of Molecular and Human Genetics,
} Baylor College of Medicine, Houston, Texas, USA

\section{Conclusion}

Our studies identify APP as synaptic adhesion and signaling molecules, which are mediated by distinct functional domains. Perturbation of these activities may contribute to synaptic dysfunction and $\mathrm{AD}$ pathogenesis.

Published: 7 February 2012

doi:10.1186/1750-1326-7-S1-L7

Cite this article as: Zheng: Deciphering the role of APP in synaptic

function. Molecular Neurodegeneration 2012 7(Suppl 1):L7.
Submit your next manuscript to BioMed Central and take full advantage of:

- Convenient online submission

- Thorough peer review

- No space constraints or color figure charges

- Immediate publication on acceptance

- Inclusion in PubMed, CAS, Scopus and Google Scholar

- Research which is freely available for redistribution
( Biomed Central
C Biomed Central

(C) 2012 Zheng; licensee BioMed Central Ltd. This is an Open Access article distributed under the terms of the Creative Commons Attribution License (http://creativecommons.org/licenses/by/2.0), which permits unrestricted use, distribution, and reproduction in any medium, provided the original work is properly cited. 